\title{
Does inspection under-rate Apprenticeship training by employers? Evidence from England
}

\author{
Paul Lewis ${ }^{a}$, Paul Ryan ${ }^{b, *}$ \\ ${ }^{a, b}$ Department of Management, King's College London
}

\begin{abstract}
A salient feature of the 'training market' through which public training programmes are often organised is the external inspection of training providers. The inspection of providers of Apprenticeship training in England has been shown to focus more on procedural than on substantive attributes. From a statistical and qualitative analysis of the content of inspection reports on training providers, we infer that this proceduralist bias distorts information on training quality by type of provider. Training sponsored by employers is made to appear less effective relative to that offered by specialist training organisations. The informational distortion is largely limited to private sector employers: other employer categories perform similarly to specialist training providers.
\end{abstract}

Keywords: training, apprenticeship, employers, inspection

\section{Introduction}

This paper addresses two issues. The first is the low participation of employers in apprenticeship training in England. In other European countries, and historically also in the UK, apprenticeship has normally involved sponsorship by an employer. In the contemporary English 'training market', however, not only is employer sponsorship not required, it is normally not present. Apprenticeship-type training is organised largely through the Apprenticeships programme. Most of the sponsors of Apprenticeships are specialist training organisations, not employers. The low commitment of employers to the Apprenticeships programme has been noted, and at times lamented (DfES, 2001; Ryan, Gospel and Lewis, 2007).

The second issue is the contribution of external inspection to the quality of training. That the quality of much of the training funded by the Apprenticeships programme is low has long been recognised by both public bodies and academics (LSC, 2004; Ryan and Unwin, 2001). The government has sought to bolster the inspection

${ }^{*}$ Corresponding author: 150 Stamford Street, London SE1 9NH. E-mail: paul.ryan@kcl.ac.uk. We would like to thank David Sherlock and Stephen Howarth of the Adult Learning Inspectorate for advice and assistance, including use of ALI's database; Uschi Backes-Gellner, Bob Butcher, Graham Cookson, Christian Dustmann, Stephen Gardner, Sharon Gilad, Howard Gospel, Niall O'Higgins, Justin Powell, Uta Schönberg, Alison Wolf, and Stefan Wolter, for advice and assistance; Dan Elias for valuable research assistance; and the Nuffield Foundation and the Faculty of Economics, Cambridge University, for financial support. None of the views expressed here are necessarily shared by those who helped us. 
of training, and thereby to increase the quality-related information available to buyers in the training market. The informational contribution of inspection has however been shown to be weak, in that it addresses primarily procedural aspects of training provision, such as management systems and records, and only secondarily substantive ones, including the achievements of trainees (Lewis and Ryan, 2009).

These apparently distinct issues may interact, for two reasons. First, the quality of training may differ systematically by type of provider. In particular, employersponsored training may be of either higher or lower quality than that sponsored by other bodies, given differences in incentives and resources. Second, the attributes of training that inspection neglects, notably the substantive ones, appear to involve bigger differences in quality between employers and other providers than those on which it focuses, notably the procedural ones. If so, judgements concerning the relative quality of employer-sponsored training will be distorted by external inspection, which may both distort the choices made by buyers of training and affect the incentive to employers to sponsor Apprenticeships.

We analyse these issues using data taken from inspections of non-college providers of Apprenticeships by the Adult Learning Inspectorate (ALI) during 2001-05. The key evidence concerns trainees' completion rates: i.e., the rate at which Apprentices complete their training programmes. This potentially informative indicator of the substantive quality of training was largely neglected in inspection practice, despite its prominence in both inspection guidelines and government policy concerns.

Section 2 outlines the analytical framework, followed in section 3 by a description of the institutional attributes of the English training market. The data used and evidence of the priority of procedural over substantive attributes in inspection verdicts are presented in section 4 . Section 5 analyses statistical differences in inspection findings and completion rates by type of provider, occupation, and skill level, followed in section 6 by qualitative evidence of biased relative evaluation of employer-sponsored programmes. The conclusions follow in section 7 .

\section{Analytical framework}

Our starting point is the determination of training quality under market-like contracting and the external inspection of training providers. A previous paper compares economic and political analyses of the issue (Lewis and Ryan, 2009).

The economic analysis assumes asymmetric information about training quality between buyers and sellers, and fixed-price contracting. It concludes that training quality will be inefficiently low, but that external inspection may offset that failure by improving buyer's information about quality, thereby increasing reputation-based incentives to providers to offer acceptable service quality. ${ }^{2}$ The analysis is potentially

\footnotetext{
${ }^{1}$ See also Lewis (2009) and Ryan (2009).

${ }^{2}$ See Chalkey and Malcomson (2000) and MacLeod (2007). Similarly, in the commitment model of Dustmann and Schönberg (2008), inspection may make it possible for employers to commit credibly to provide high quality training.
} 
relevant to the UK training market, with its contractual relationships, fixed-price contracts, and extensive inspection system.

The political science approach leads to less optimistic conclusions. The quality of public training programmes is seen as suffering from conflict between constraints on government spending and political pressure to make the service widely available: within a given budget, higher participation means less expenditure per person, and thereby lower quality. Politicians improve their electoral prospects by giving quantity priority over quality, given the greater political visibility of quantity over quality. Inspection focuses on what is readily visible: procedure rather than content. Its principal function is public reassurance, by way of the papering over of cracks, rather than the provision of valid evidence on quality. Inspection obfuscates rather than informs. $^{3}$

In a recent analysis of inspection reports on providers of Apprenticeship training in England, we found a systematic neglect of a particular substantive attribute of training quality: 'learners' achievements', i.e., the rate at which trainees stay in training and complete their programmes. Inspection teams did not process the information on trainee retention and completion that was, or at least should have been, given to them by the provider. The inspectors' overall verdicts on providers depended heavily on procedural attributes and only marginally on substantive ones, including trainee retention and completion rates, and the quality of learning sessions. As such, inspection practice proved consistent more with the political than with the economic interpretation (Lewis and Ryan, 2009).

Taking those findings as background, we examine here the implication of 'proceduralist bias' for public assessments of the various types of provider that operate in the English training market. Inspection results may well distort evaluations of different types of training provider, in particular those of employers relative to specialist training organisations.

The effect of inspection on the perceived relative performance of employers' programmes may in principle be positive or negative. A negative effect might be hypothesised on the basis of financial attributes. The funds available to specialist training organisations are typically limited to their public training grant. Such organisations stand to make losses if they spend more than their public training grants. By contrast, employers' outlays on their Apprentices need not be restricted to the public subsidy. As a prospective future beneficiary of the resulting skills, the employer has an incentive to invest more than the public grant in each trainee, which should increase substantive quality by leading to more learning per trainee. Instances of expenditures greater than public training grants include large metalworking employers, many of whom invest in their Apprentices more than three times the public subsidy. ${ }^{4}$

Such differences in dependence on public contracts may lead to differences in compliance with the procedural requirements of public programmes. Commercial

\footnotetext{
${ }^{3}$ See Pierson (1996), Power (1999) and Lewis and Ryan (2009: section 2.2).

${ }^{4}$ Hogarth and Hasluck (2003), Ryan, Gospel and Lewis, (2007).
} 
training specialists, having typically no alternative revenue source, face a particularly strong incentive to comply with the procedural requirements imposed by the public buyer and monitored by external inspection. Employers, to the extent that they depend for their revenues more on product markets than on public training programmes, enjoy greater scope to neglect externally imposed procedural requirements.

The prediction of a bias against employer programmes in inspection findings has potential exceptions. Some employers are financially insecure and poorly placed to invest additionally in Apprentices' skills. The category includes smaller firms, and local authorities subject to tight fiscal controls by central government. Conversely, some charities possess independent endowments that allow them to devote core funding to their training activities rather than relying entirely on contractual income, and thus to spend more than the public training grant on each trainee.

The alternative hypothesis might well be a positive effect of proceduralist bias on the assessed performance of employers. The reasons for an employer to provide work-based training under public subsidy include not only investment in its future skills supply, but also the acquisition of a current labour supply - even, in the extreme, the use of trainees as cheap labour. Surveys of employers' costs for apprentice training have established the dominance of the latter ('production') motive over the former ('investment') one in particular firms and sectors in economies as different as Germany, Switzerland and the UK. ${ }^{5}$

Employers with a 'production' motive for taking on Apprentices may offer lower quality training than that provided by specialist training organisations. The Apprenticeships programme provides exceptional scope for such a pathology, given the weakness of the external regulation of training content, the dominance of internal assessment of work-based learning, and the paucity of off-the-job training, let alone educational content, in training requirements in service occupations. ${ }^{6}$ Any bias in inspection towards procedural attributes would then be expected to weaken the evidence of low substantive quality in such programmes.

The potential over-rating by inspection of the training provided by employers who take a 'production' approach is however likely to be offset by an institutional feature of the UK training market: such employers are more likely to participate as subcontractors for the work-based training component than as principal contractors for an Apprenticeship programme as a whole. The training programmes in which such employers are involved are then sponsored by the specialist training organisation that holds the principal contract, and any tendency to low quality can be expected to show up in that category rather than in the 'private employer' one. The

\footnotetext{
${ }^{5}$ von Bardeleben, Beicht and Féher (1995), Schweri et al. (2003), Hogarth and Hasluck (2003). A similar distinction, between expansive and restrictive approaches by employers to Apprenticeships, has been proposed by Fuller and Unwin (2008). The relative quality of employer programmes may also be low as a result of the incentive to the employer to orient training content to its own skill requirements - i.e., toward specific rather than transferable skills - which reduces training quality, from the social standpoint at least (Stevens, 1996; Smits, 2005).

${ }^{6}$ Ryan (2000), Ryan, Gospel and Lewis (2006).
} 
latter category would then be restricted largely to companies adopting an 'investment' approach to training. ${ }^{7}$

Given this institutional attribute, we hypothesise that (i) Apprenticeships sponsored by an employer are of substantively higher quality on average than those by other providers, and (ii) proceduralist bias leads external inspection to under-estimate the quality of such employers' programmes relative to those of specialist training providers. 'Production'-oriented employers are expected to be concentrated invisibly in the latter category. At the same time, the heterogeneity of employer motivation and participation means that the situation may differ by sector, occupation, and firm size.

\section{Institutional context}

Publicly funded work-based training for young people in England has been organised in this decade through what is now the Apprenticeships programme. Its two streams were until 2004 called Foundation Modern Apprenticeship, comprising occupationally-oriented programmes pitched at Level 2 in the vocational dimension of the National Qualifications framework, and Advanced Modern Apprenticeship, comprising Level 3 programmes. The programme has since 2002 contained three components: 'competence', or practical skills, as certified by a National Vocational Qualification (NVQ); applied literacy and numeracy, as assessed by Key Skills certification; and 'underpinning knowledge', as represented by a Technical Certificate. The eleven Areas of Learning (i.e., occupation-cum-sector categories) into which Apprenticeships are classified include both those with a history of apprentice training, notably engineering and construction, and those previously devoid of apprenticeship, notably retailing and business administration.

The Apprenticeships programme is administered by the Learning and Skills Council (LSC), a non-departmental public body. The LSC provides grants, which in 2004 varied between $£ 1,000$ and $£ 15,000$ per Apprentice, as to age and Area and Level of Learning, for work-based learning by young people (LSC, 2003a).

The Apprenticeships programme shows a complex pattern of provision, which diverges substantially from both British tradition and contemporary foreign practice. While every Apprentice's programme is - or, rather, was initially - required to involve work-based training with an employer, and while the LSC encourages employers to give their Apprentices employee status, the employer's contribution varies greatly in practice. At one pole, the employer acts as prime contractor - here 'sponsor' and provides most or all of the training itself. At the other extreme, the employer acts only as the sub-contracting provider of on-the-job training and work experience

\footnotetext{
${ }^{7}$ The situation is complicated further by the widespread, and probably increasing, tendency of large employers with reputable training programmes to contract out formal responsibility for Apprenticeship to a training company or further education college, in order to avoid the administrative burdens of dealing with the public funding body (Ryan, Gospel and Lewis, 2006). A contemporary example is BT's contract with Accenture to organise its sizeable Apprenticeship programme.
} 
for Apprentices sponsored by an external provider. Other employers play an intermediate role, providing much of the training themselves, but leaving it to a training specialist to hold the main contract with the LSC, and typically to assess learners' achievements itself. This heterogeneity makes it particularly difficult to assess the extent of employer participation in Apprenticeship training.

Similar complexity characterises the role of further education colleges, who traditionally provided apprentices with their part-time technical education under day (or block) release. The role of colleges has both shrunk and expanded relative to traditional apprenticeship. It has shrunk, in that many Apprenticeship programmes, particularly in the service sector, involve little or no off-the-job learning, let alone formal technical education. Those that do contain off-the-job learning may not involve a further education college, but rather a training company or self-provision by the relevant employer. ${ }^{8}$ It has expanded, in that many colleges are prime contractors for Apprenticeships, subcontracting with employers for work-experience and on-the-job training. ${ }^{9}$ Some colleges, under 'programme-led Apprenticeships', which lack any workplace-based component, have since 2004 even provided entire Apprenticeship programmes themselves. ${ }^{10}$

The recasting of the roles of employers and colleges in British apprenticeship has been complemented by the rapid expansion of specialist training providers, both for-profit and non-profit. In addition to sponsoring their own Apprenticeship programmes, such organisations frequently assess for other sponsors their Apprentices' attainments in work-based competence and Key Skills.

The shares of five categories of training provider among non-college principal contractors for LSC-funded work-based learning programmes are shown in columns one and two of Table $1 .{ }^{11}$ Specialist training companies are the largest group, accounting for nearly one half of both providers and trainees. If non-profit training organisations are included, the specialist share rises to 61.1 per cent of providers and 64.7 per cent of trainees. Employers training their own employees constitute only 28.5 per cent of providers and 17.2 per cent of trainees. Around half of those employers are public bodies, mostly local authorities and hospitals. Private sector employers account for only 14.4 per cent of providers and 4.3 per cent of trainees. However, the private employer share rises to 24.8 per cent of providers and 22.7 per cent of trainees if employer groups, a diverse category composed overwhelmingly of private sector employers, are included.

\footnotetext{
${ }^{8}$ Ullman and Deakin (2005), Ryan, Gospel and Lewis (2006).

${ }^{9}$ Statistics on college provision of Apprenticeships are scanty. A review of Modern Apprenticeship reported that some 186 general further education colleges were involved in recruiting employers, not just young people, into work-based learning programmes, including Modern Apprenticeship (DfES/LSC, 2004: 13). Similarly, a detailed analysis for a major industrial region reported that 38 out of 188 providers of work-based learning were further education colleges (LSC, 2003b: 25).

${ }^{10} 14.4$ per cent of Apprentices took the 'FE programme led pathway' in 2004-5 (DfES, 2007).

${ }^{11}$ The classification of providers by category is taken from ALI's database. The population of inspected providers during a four year period differs from the population of all providers at a point in time, despite mandatory inspection, insofar as during the period some providers entered the market too late to be inspected and others left it before being inspected.
} 
Table 1: Shares of training providers and Apprentices by provider category, 2001-05 $(\%)$

\begin{tabular}{lcccc}
\hline & \multicolumn{2}{c}{ All providers } & \multicolumn{2}{c}{ Retained providers } \\
& $\begin{array}{c}\text { Share of } \\
\text { training } \\
\text { providers }\end{array}$ & $\begin{array}{c}\text { Share of } \\
\text { Apprentices: } \\
\text { five Areas } \\
\text { only }\end{array}$ & $\begin{array}{c}\text { Share of } \\
\text { training } \\
\text { providers }\end{array}$ & $\begin{array}{c}\text { Share of } \\
\text { Apprentices: } \\
\text { five Areas } \\
\text { only }\end{array}$ \\
\hline Employer: private & 14.4 & 4.3 & 9.7 & 4.0 \\
Employer: public & 14.1 & 15.2 & 17.4 & 15.4 \\
Employer group & 10.4 & 26.1 & 17.2 & 31.7 \\
Trainer: for-profit & 47.1 & 41.9 & 44.1 & 34.5 \\
Trainer: non-profit & 14.0 & 12.5 & 11.5 & 14.3 \\
All & 100.0 & 100.0 & 100.0 & 100.0 \\
$\mathrm{n}$ & 943 & 165,277 & 442 & 100,452 \\
\hline
\end{tabular}

Notes:

Shares of providers and trainees at the time of inspection for (i) all 943 providers in the ALI inspections database, including those for which an inspection report could not be located on the ALI website, and (ii) 442 retained providers, i.e., those with Apprentices in at least one Area of Learning and an inspection report providing usable data on trainee outcomes.

'Five Areas only': Apprentices in the five selected Areas of Learning, excluding trainees in other LSC-funded programmes, such as 'NVQ only' training.

Definitions:

1. Employer, private: for-profit companies training their own employees.

2. Employer, public: local authorities, health authorities, educational institutions, armed forces, and other.

3. Employer group: group training associations, employers' associations, Chambers of Commerce, and Industry Training Boards.

4. Trainer, for-profit: companies who provide training and related services for individuals who are not their own employees.

5. Trainer, non-profit: non-profit organisations, including charities and companies limited by guarantee, who provide training and related services for individuals who are not their own employees.

Inspection has been the responsibility of the Adult Learning Inspectorate (ALI), a non-departmental government body set up in 2001 to inspect on a four yearly cycle all non-college organisations holding an LSC contract for the supply of work-based training. It was to inform the government about 'the quality of education and training' and to 'help bring about improvement by identifying strengths and weaknesses and highlighting good and poor practice' (ALI, 2002a: 4).

At the end of an on-site visit to a training provider, and guided by the Common Inspection Framework, inspection teams awarded grades for five aspects of overall provision: Leadership \& Management; Quality Assurance; Equality of Opportunity; Areas of Learning (Occupation/Curriculum); and Learning Sessions. Most reports also included data on trainee flows and outcomes, i.e., numbers entering, staying in ('retained'), and completing training, by Area and Level of Learning and by year of entry - though no report suggested that those data had been used to calculate 
retention and completion rates. Many reports also provided qualitative evidence of other attributes, such as the presence of a specialist training facility and training beyond the requirements of the relevant Apprenticeship framework. The inspectors summarised their findings by classing the provider's training as either 'adequate' or 'not adequate'. The inspection report was subsequently published on ALI's website. Providers rated inadequate were subject to re-inspection within two years. ${ }^{12}$

\section{Data and prior results}

Our data are taken from the 943 inspection reports published by ALI between its inception in March 2001 and July 2005 that could be accessed on its website in August 2005 for principal contractors to the Apprenticeships programme ${ }^{13}$ in one or more of five Areas of Learning: construction, engineering, business administration, information and communications technology (ICT), and retailing. The five Areas were selected so as to include the great majority of Apprentices and a range of occupations and sectors. ${ }^{14}$

Further education colleges could not be included as the inspection of their programmes was organised differently, with a limited reporting format. ${ }^{15}$

We retain the 442 reports that provide usable information not only on qualityrelated attributes for the provider as a whole but also on trainee flows into and out of training in at least one Area-Level category (e.g., construction Level 2). From the latter data we calculate Apprentice retention and completion rates. Trainee outcomes are measured for an average of 1.9 cohorts per provider. The median first year of Apprentice entry is 1998-99. The data cover almost 100,000 entering Apprentices, 58 per cent of whom trained for retailing or business administration. Slightly more trainees entered Level 3 than Level 2 programmes. ${ }^{16}$

Discarding more than half of the inspection reports reduces the shares of both private employers and training companies, and increases the share of both public employers and employer groups (Table 1, columns 1 and 3,2 and 4). These changes indicate that data on trainee flows and outcomes are less frequently compiled for (or used by) inspection teams in the case of private employers and training companies than of public employers and employer groups. They also raise the possibility of sample selection bias. Thus, if providers who do not compile data on trainee outcomes tend to offer poorer training, our sample will be biased toward better quality

\footnotetext{
${ }^{12}$ ALI was merged into the schools inspectorate (OfSTED) in 2007. A more detailed account of external inspection is provided by Lewis and Ryan (2009). See also Perry and Sherlock (2008).

${ }^{13}$ We use the programme's current title, 'Apprenticeships', instead of the previous title, 'Modern Apprenticeship'. We capitalise the term to indicate that we refer to a government programme that overlaps, but is not coterminous, with 'apprenticeship' as that term has been understood in other times and places.

${ }^{14}$ Apprentices in the five selected Areas of Learning accounted at the time of inspection for 87 per cent of $(196,945)$ Apprentices across all twelve Areas (in the population of 943 providers).

${ }^{15}$ Five providers (in the population of 943 inspected ones) use the name of a public college, typically as a separate organisation set up by the college to contract with the LSC (e.g., Northallerton College Training Services).

${ }^{16}$ See Lewis and Ryan (2009), Table 1.
} 
provision. Any such bias need not however affect our comparison of performance across different types of provider.

The Apprenticeship programme is known to be highly heterogeneous, with marked differences between long established and recently established Areas of Learning. Method of provision varies considerably across Areas of Learning (Table 2, covering all work-based learning). All types of provider are present in all Areas of Learning, but the contribution of particular categories differs by Area. The share of private employers is negligible in business administration and retailing. In construction, most of the training is sponsored by employer groups; in retailing and business administration, by training companies. Public sector employers are the largest category in IT.

Table 2: Shares of provider categories in training volume by Area of Learning (\%)

\begin{tabular}{lcccccc}
\hline & $\begin{array}{c}\text { Const- } \\
\text { ruction }\end{array}$ & $\begin{array}{c}\text { Engin- } \\
\text { eering }\end{array}$ & $\begin{array}{c}\text { Bus } \\
\text { Admin }\end{array}$ & ICT & $\begin{array}{c}\text { Retail- } \\
\text { ing }\end{array}$ & All five \\
\hline Employer: private & 1.9 & 6.4 & 0.4 & 6.3 & 1.8 & 3.2 \\
Employer: public & 6.2 & 23.5 & 13.7 & 42.8 & 3.3 & 14.0 \\
Employer group & 50.8 & 39.9 & 13.1 & 5.6 & 10.3 & 29.6 \\
Trainer: for-profit & 9.8 & 22.4 & 59.4 & 37.5 & 74.2 & 38.3 \\
Trainer: non-profit & 31.3 & 7.8 & 13.3 & 7.8 & 10.4 & 14.8 \\
All & 100.0 & 100.0 & 100.0 & 100.0 & 100.0 & 100.0 \\
& & & & & & \\
$\mathrm{n}$ & 29032 & 41577 & 24171 & 4813 & 27469 & 127062 \\
\hline
\end{tabular}

Note: trainees (Apprentices and others) at the time of inspection; 442 retained providers.

The median inspection verdict across all 442 providers is 'adequate'; the median grade for detailed attributes is 'satisfactory' for all except Quality Assurance. Median retention and completion rates are however low, at 50 and 38 per cent respectively. Trainee outcomes are also highly dispersed: the completion rate at the lower quartile is only 11 per cent, as against 61 per cent at the upper quartile.

Evidence pointing to proceduralist bias in inspection findings, as provided by Lewis and Ryan (2009: Tables 4, 5), comprises firstly higher correlations between the overall verdict on a provider (Adequacy) and grades given for such procedurally oriented attributes of provision as Leadership \& Management than between the same verdict and substantive attributes such as Learning Sessions and, in particular, retention and completion rates. The pattern was confirmed by a multivariate probit analysis of inspection verdicts. Secondly, correlations between the procedural and substantive attributes, while all significantly positive, are much smaller than those within each group of attributes. Thirdly, the re-inspection of providers who failed their initial inspection focuses entirely on procedural criteria. This evidence suggests that, while both procedural and substantive attributes influence inspection verdicts, the dominant influence comes from the procedural side. ${ }^{17}$

\footnotetext{
${ }^{17} \mathrm{~A}$ further substantive weakness of the inspection system is neglect of the low incidence of qualifica-
} 


\section{Statistical results}

The bias toward procedural attributes in ALI's inspections, which reduces their informational content as a whole, may also distort assessments of the relative quality offered by the various types of provider.

Table 3 breaks down inspection results by type of provider. Taking all five Areas of Learning together, median grades for the five qualitative criteria differ little across provider types. The median member of most or all categories of provider is graded 'satisfactory' for Leadership and Management, Equality of Opportunity, Areas of Learning (O/C), and Learning Sessions; and 'unsatisfactory' for Quality Assurance.

What differences there are across provider types largely favour employers in general, and private sector employers in particular. The median overall verdict in the three employer categories is 'adequate', whereas that for both categories of specialist training provider is 'inadequate'. Employers, both private and public, are the only providers to earn a median grade of 'satisfactory' for Quality Assurance; and private employers, to be rated 'good' for Areas of Learning. By contrast, the median grades given to specialist training organisations are 'unsatisfactory' for both Leadership and Quality Assurance, in the case of for-profit providers, and for Quality Assurance in the case of non-profit providers as well.

The hypothesis that the median grade is the same in all provider categories is statistically rejected for all five attributes. The principal cause is the superior performance of private sector employers: when the hypothesis is applied to the median grade across the other four provider categories, i.e., excluding private sector employers, it is not rejected, either for Adequacy or for four of the five detailed attributes.

The differences between employers and other providers in Table 3 are more striking when it comes to trainee outcomes, which we interpret as a valid indicator of substantive training quality. ${ }^{18}$ Private employers' median retention and completion rates, at 83 and 77 per cent, respectively, are an order of magnitude larger than those of other providers, which lie around 50 per cent and less than 40 per cent respectively. Public employers also do better than non-employer providers, but by a smaller margin. Training companies bring up the rear, with retention rates of less than one-half (46 per cent), and completion rates of only one-third (33 per cent). At first glance, therefore, the evidence suggests that external inspection favours employers. Indeed, private sector employers come out on top on almost all criteria. Among the other four categories of provider, neither public sector employers nor employer groups

tions, both occupational and pedagogical, among training staff (Rose and Wiganek, 1990). Our findings contradict the view, reportedly common among training providers, that '... providers were usually only given ... high inspection grades if a large proportion of their learners met all the requirements of their modern apprenticeship framework. Some felt that a disproportionate weight was given to the rate for successful completion of modern apprenticeships and that other factors should be taken into consideration as evidence of quality and good performance' (LSC, 2003b: 24).

${ }^{18}$ Causality may run both ways between training quality and trainee outcomes: e.g., better programmes induce more trainees to complete, and providers who want more trainees to complete offer better programmes. 
stand out strongly either way.

That does not however settle the issue. The large difference in retention and completion rates between private employers and other providers is not mirrored in comparably large differences between private employers and other providers, whether in grades for Areas of Learning $(\mathrm{O} / \mathrm{C})$, which, according to ALI's procedural mandate, should reflect trainee progress, nor, crucially, in Adequacy as a whole.

That pattern is consistent with the much greater influence on inspection outcomes of procedural criteria, notably Leadership \& Management, than of substantive ones (Learning Sessions and trainee outcomes). In other words, while private sector employers do fare better than other providers in inspection results, the difference in their favour would be even greater were more weight given to retention and completion rates, the area in which their performance outstrips considerably that of other providers. In that sense, the inspection system under-rates the performance of employers in general, and that of private sector employers in particular.

The inference must however be qualified on three grounds, the empirical significance of which will be explored further below. First, grades for Adequacy, Leadership, etc., are ordinal variables, and any specific difference in them across providers is logically consistent with both larger and smaller absolute differences in the cardinal variables - trainee outcomes - that are supposed to help determine them.

Second, in our data only 43 principal contractors are private sector employers. Moreover, as Table 4 shows, most of the private sector employers who sponsor Apprenticeship do so in engineering. Indeed, more than half (52.5 per cent) of private sector employers' entering Apprentices go into Level 3 engineering programmes. The experience of these employers may therefore provide a less than fully valid and reliable guide to what would prevail were more employers involved in the Apprenticeship programme, particularly in other Areas and Levels of Learning. Indeed, what appears in Table 3 to be a private employer effect on completion rates may simply be an Area or Level effect: e.g., high completion rates in Level 3 training in engineering as a whole.

Third, while higher retention and completion rates might provide valid evidence of better training within a provider category, the superior performance of private sector employers on those criteria might be expected to result from more factors than simply training quality. Both the context of training and the manner of selection into it may influence retention and completion rates. In terms of context, training may be expected to lead more directly to employment in general, and to a permanent contract in particular, when it is sponsored by an employer than by a specialist trainer. Young people may then have more incentive to complete a programme of given quality when it is sponsored by the former rather than the latter. Indeed, if their training is organised by a specialist provider, they have a particular incentive to drop out of training if offered a job before the end of their programme. 
Table 3: Median inspection grades and Apprentices' outcomes by provider category

\begin{tabular}{|c|c|c|c|c|c|c|c|c|}
\hline \multirow[b]{2}{*}{ Inspection attribute } & \multicolumn{6}{|c|}{ Median provider grade or trainee outcome ${ }^{a}$} & \multicolumn{2}{|c|}{ Reject equality of medians? } \\
\hline & $\begin{array}{c}\text { Employer } \\
\text { private }\end{array}$ & $\begin{array}{c}\text { Employer } \\
\text { public }\end{array}$ & $\begin{array}{c}\text { Employer } \\
\text { group }\end{array}$ & $\begin{array}{c}\text { Trainer } \\
\text { for-profit }\end{array}$ & $\begin{array}{c}\text { Trainer } \\
\text { non-profit }\end{array}$ & All & $\begin{array}{c}\text { All } \\
\text { categories }\end{array}$ & $\begin{array}{l}\text { Excluding } \\
\text { private } \\
\text { employers }\end{array}$ \\
\hline 1. Adequacy & 1 & 1 & 1 & 0 & 0 & 1 & Yes & No \\
\hline 2. Leadership \& Management & 3 & 3 & 3 & 2 & 3 & 3 & Yes & No \\
\hline 3. Quality Assurance & 3 & $2,3^{d}$ & 2 & 2 & 2 & 2 & Yes $^{c}$ & No \\
\hline 4. Equality of Opportunity & 3 & 3 & 3 & 3 & 3 & 3 & Yes $^{c}$ & No \\
\hline 5. Areas of Learning $(\mathrm{O} / \mathrm{C})$ & 4 & 3 & 3 & 3 & 3 & 3 & Yes & Yes $^{c}$ \\
\hline 6. Learning Sessions & 5 & $4,5^{d}$ & 5 & $4,5^{d}$ & 5 & 5 & $\mathrm{Yes}^{c}$ & No \\
\hline 7. Retention rate (\%) & 82.8 & 53.3 & 47.0 & 45.6 & 51.2 & 50.3 & Yes & No \\
\hline 8. Completion rate $(\%)$ & 76.5 & 40.1 & 39.5 & 33.1 & 38.2 & 38.2 & Yes & No \\
\hline $\mathrm{n}: \# 1-5,8$ & 43 & 77 & 76 & 195 & 51 & 442 & & \\
\hline \#6 & 24 & 58 & 48 & 160 & 35 & 325 & & \\
\hline \#7 & 40 & 64 & 65 & 157 & 45 & 371 & & \\
\hline
\end{tabular}

Notes:

${ }^{a}$ Adequacy (0: inadequate; 1: adequate); Leadership \& Management to Areas of Learning (1: very weak; 2: unsatisfactory; 3: satisfactory; 4: good; 5: outstanding); Learning Sessions (1: very poor ...; 4: satisfactory ...; 7: excellent). The completion rate is $(\mathrm{C} /(\mathrm{S}-\mathrm{L}))$, the retention rate as $(\mathrm{R} / \mathrm{S})$, where $\mathrm{S}$ is the number of entrants (starts), $\mathrm{R}$ is the number of entrants retained (i.e., remained in training for the LSC's standard programme duration or completed before then), C is the number of those entrants who completed their training programme at any point before the inspection, and $\mathrm{L}$ is the number of entrants still in learning at time of inspection

${ }^{b} \chi^{2}(\mathrm{p}=.05)$; observations equal to the overall median are divided equally between adjacent grades before testing

${ }^{c}$ Hypothesis rejected despite the constancy (near or total) of the median grade across categories because of other differences in the distributions

${ }^{d}$ Median lies between the two grades 
Table 4: Private sector employers: numbers and shares of Apprentices by Area

\begin{tabular}{lcccc}
\hline \multirow{2}{*}{ Area of Learning } & \multicolumn{2}{c}{ Number } & \multicolumn{2}{c}{ Share (\%) of } \\
Providers $^{a}$ & Trainees $^{b}$ & Providers $^{a}$ & Trainees $^{b}$ \\
\hline Construction & 2 & 561 & 2.5 & 1.9 \\
Engineering & 31 & 2657 & 15.3 & 6.4 \\
Business Administration & 5 & 95 & 1.7 & 0.4 \\
ICT & 3 & 301 & 3.5 & 6.3 \\
Retailing & 6 & 493 & 2.8 & 1.8 \\
Any (of five) & 43 & 4107 & 9.7 & 3.2 \\
\hline
\end{tabular}

Notes: $\mathrm{n}=442$ (retained providers only)

${ }^{a}$ private sector employers with trainees in any LSC-funded programmes in the Area

${ }^{b}$ number of trainees in the Area at inspection as a share of all trainees in all providers in the Area

In terms of selection, employers should be able to choose better trainees, who are more likely to complete training, independently of its quality. Employers offering Apprenticeships commonly accept only applicants with specific levels of attainment in compulsory schooling, e.g., five GCSE subjects at grade $\mathrm{C}+$, including English and maths. By contrast, many specialist providers accept anyone eligible for public funding, and some, particularly non-profit organisations, actively cater to low achievers (Ryan, Gospel and Lewis, 2006).

This interpretation of the link between completion rates and training quality does not however explain the superiority of trainee outcomes for private sector employers over those for public sector employers and employer groups - both of which should be similar to solo companies when it comes to offering employment after training, and possibly also to recruiting able young people. Moreover, other research finds that completion rates for employers as a whole are reduced by employer choices, whether to ensure that the young person remains an employee or because the employer does not value the uncompleted parts of the training programme (Winterbotham et al., 2000). Indeed, the great majority of Apprentices - and not just those sponsored by a private employer - spend part or all of their time in work-based training and work experience, and as such constitute potential recruits for the employer that provides their work-based training before they have completed their programmes.

An assessment of the validity of the latter two potential explanations of the higher completion rates of private employers requires statistical controls for other potential determinants of completion rates, including trainee ability, size of training operation, and training occupation. That is to some extent possible, using other data taken from inspection reports. Private employers' programmes are on average smaller, more frequently 'country-wide' in coverage, and much more frequently limited to a single Area of Learning (Table 5). To the extent that completion rates vary with those factors, the robustness of the employer effect on completion can be examined by including them in a regression analysis of completion rates. ${ }^{19}$

\footnotetext{
${ }^{19}$ Other research on work-based learning programmes has found provider specialisation to be positively associated with performance (LSC, 2003b).
} 
Table 5: Characteristics of Apprenticeship programmes by category of provider

\begin{tabular}{|c|c|c|c|}
\hline & $\begin{array}{l}\text { Average number } \\
\text { of trainees }\end{array}$ & $\begin{array}{c}\text { Share of } \\
\text { providers that } \\
\text { are country- } \\
\text { wide }^{b}(\%)\end{array}$ & $\begin{array}{c}\text { Share of } \\
\text { providers with a } \\
\text { single Area of } \\
\text { Learning }^{c}(\%)\end{array}$ \\
\hline Employer: private sector & 100.2 & 28.9 & 90.7 \\
\hline Employer: public sector & 241.6 & 1.3 & 24.7 \\
\hline Employer group & 489.4 & 7.8 & 36.8 \\
\hline Trainer: for-profit & 240.8 & 11.1 & 22.1 \\
\hline Trainer: non-profit & 350.2 & 24.1 & 15.7 \\
\hline All & 283.3 & 12.2 & 24.7 \\
\hline
\end{tabular}

Notes: $n=442$

${ }^{a}$ number of trainees in the five Areas (all programmes, including Apprentices) at the time of inspection

${ }^{b}$ providers of any LSC-funded work-based learning in more than two regions

${ }^{c}$ trainees (including Apprentices) in only one of 11 Areas of Learning

We therefore start with statistical controls for size of provider (number of trainees) and country-wide status. The effect of private employer sponsorship on completion rates remains strongly positive: the estimated differential relative to training companies is 33 percentage points (Table 6 , column 1). ${ }^{20}$ The differential between public employers and training companies is much smaller, at 7.5 points, but it too is positive and statistically significant. Employer groups and non-profit training specialists are however statistically indistinguishable from training companies. Programme size has a mixed effect: positive in the selected five Areas, but negative for all eleven Areas.

When controls are also introduced for the particular Areas of Learning in which a provider operates, the best estimate of the private employer effect falls moderately, to 27.5 points, and that for public employers becomes statistically insignificant (Table 6 , column 2). The only Area in which completion rates differ systematically from the five Area norm is retailing, in which the estimated rate is nearly 10 points lower. Programme size effects become insignificant.

The private employer effect falls more strongly when further controls are imposed for the extent of providers' specialisation by Area of Learning. Providers who train in one Area only are estimated to have an average completion rate 11.5 points above the norm; and those who train in engineering AMA (Level 3) only, a further 16 point difference. The private employer effect is halved by these adjustments. In other words, part of the simple association between private employer status and trainee completion does indeed reflect the tendency of the private employers engaged in Apprenticeships to specialise in a single Area of Learning, particularly in Level

\footnotetext{
${ }^{20}$ We use for simplicity a linear probability rather than a logistic specification, given the paucity of observations close to the boundaries ( 0 and 100 per cent). The results of a similar analysis of retention rates are not reported, as the results were similar to those for completion but statistically less well defined, given the smaller sample size.
} 
3 engineering, and not to operate in retailing - but not the smaller size of their programmes, nor their tendency to operate on a wider territorial basis. ${ }^{21}$ However, at 14.9 points, the net employer effect on completion rates remains economically large and statistically significant.

These results cannot however be taken to have isolated the 'pure' private employer effect, given potentially powerful selection effects among both trainees and employers. As argued in section 2, in terms of trainee selection, the effects of trainee quality on completion rates are potentially strong; in terms of employer selection, employers who act as principal contractors for Apprenticeships are expected more commonly to adopt an 'investment' than a 'production' approach to Apprentice training. Data with which to control for these selection effects are not however available. $^{22}$

Subject to that reservation, the evidence suggests firstly that inspection underrates the training programmes of employers, because of the marginal status it assigns to completion rates in assessing providers' performance. Secondly, the superiority of employers' programmes is overwhelmingly a matter of the superiority of private sector employers who sponsor their own training programmes. The performance of public employers and employer groups lies closer to that of specialist training organisations that to that of private sector employers.

Proceduralist bias in external inspection might be expected also to cause employers, particularly private sector ones, to crop up with disproportionate frequency among providers rated 'inadequate' despite having a high completion rate, in association with low grades for Leadership \& Management. ${ }^{23}$ If a high completion rate is defined as one in the upper quartile of the distribution - here, at least 61 per cent - twenty-two providers satisfy that criterion but still fail the inspection. Eleven are employers, a share that is significantly larger than the share of employers among providers as a whole $\left(\chi^{2}=5.14 ; \mathrm{p}<0.05\right.$, one tail test $)$. Although eight of those eleven are public bodies, the three private sector ones are among the eight providers with the highest completion rates in the category (Table 7, panel I).

\footnotetext{
${ }^{21}$ Standard errors on the key coefficients in Table 6 do not increase substantially when the additional control variables are introduced, which suggests that multicollinearity is limited. The number of private employers outside Level 3 engineering may be small, but the number of non-employer providers is substantial even in Level 3 engineering, which ensures the statistical separability of the effects of private employer and sector-Level status.

${ }^{22}$ An analysis of selection effects among employers would require data on employers who do not participate in Apprenticeships, or do so only indirectly, from which a participation equation could be estimated and the results used in an attempt to control for selection into principal contractor status.

${ }^{23}$ Similarly, an OfSTED inspection failed a school for serious weaknesses in management systems despite having $88 \%$ of lessons rated at least satisfactory (Weiner, 2002).
} 
Table 6: Regression analysis of Apprentices' completion rate

\begin{tabular}{|c|c|c|c|}
\hline & $(1)$ & $(2)$ & (3) \\
\hline \multirow[t]{2}{*}{ Private employer } & $33.3^{*}$ & $27.5^{*}$ & $14.9 *$ \\
\hline & $(4.1)$ & $(4.2)$ & $(4.8)$ \\
\hline \multirow[t]{2}{*}{ Public employer } & $7.5^{*}$ & 4.9 & 5.5 \\
\hline & $(3.1)$ & (3.2) & $(3.1)$ \\
\hline \multirow[t]{2}{*}{ Employer group } & 2.5 & 1.3 & 0.9 \\
\hline & (3.1) & $(3.5)$ & $(3.3)$ \\
\hline \multirow[t]{2}{*}{ Trainer: non-profit } & 1.3 & 0.6 & 1.2 \\
\hline & (3.7) & (3.6) & $(3.5)$ \\
\hline \multirow[t]{2}{*}{ Number of trainees (5 Areas) ${ }^{a}$} & $0.81 *$ & 0.51 & 0.38 \\
\hline & $(0.41)$ & $(0.41)$ & $(0.40)$ \\
\hline \multirow[t]{2}{*}{ Number of trainees (all Areas) ${ }^{a}$} & $-0.78 *$ & -0.44 & -0.30 \\
\hline & $(0.39)$ & $(0.39)$ & $(0.38)$ \\
\hline \multirow[t]{2}{*}{ Country-wide provider } & -2.0 & -2.4 & -2.3 \\
\hline & $(4.2)$ & $(4.1)$ & $(4.0)$ \\
\hline \multirow[t]{2}{*}{ Trains in construction ${ }^{b}$} & & -6.4 & -6.2 \\
\hline & & $(4.4)$ & $(4.2)$ \\
\hline \multirow[t]{2}{*}{ Trains in engineering ${ }^{b}$} & & -1.5 & -1.3 \\
\hline & & (3.0) & (2.9) \\
\hline \multirow[t]{2}{*}{ Trains in business administration ${ }^{b}$} & & -2.9 & 1.2 \\
\hline & & $(2.5)$ & $(2.6)$ \\
\hline \multirow[t]{2}{*}{ Trains in $\mathrm{ICT}^{b}$} & & -0.5 & 0.2 \\
\hline & & $(4.2)$ & $(4.2)$ \\
\hline \multirow[t]{2}{*}{ Trains in retailing $^{b}$} & & $-9.5^{*}$ & $-6.5^{*}$ \\
\hline & & $(2.7)$ & $(2.7)$ \\
\hline \multirow[t]{2}{*}{ Trains in one Area only } & & & $11.4^{*}$ \\
\hline & & & $(2.9)$ \\
\hline \multirow[t]{2}{*}{ Trains in engineering Level 3 only } & & & $16.0^{*}$ \\
\hline & & & $(5.1)$ \\
\hline \multirow[t]{2}{*}{ Year 2002} & 1.6 & 3.5 & 3.2 \\
\hline & $(3.2)$ & $(3.2)$ & $(3.1)$ \\
\hline \multirow[t]{2}{*}{ Year 2003} & 2.8 & 3.5 & 3.6 \\
\hline & (3.4) & (3.4) & $(3.3)$ \\
\hline \multirow[t]{2}{*}{ Year 2004} & $8.4^{*}$ & 7.2 & $7.8^{*}$ \\
\hline & $(4.0)$ & (3.9) & $(3.8)$ \\
\hline \multirow[t]{2}{*}{ Year 2005} & 8.2 & 9.1 & 8.1 \\
\hline & $(6.8)$ & $(6.6)$ & $(6.5)$ \\
\hline \multirow[t]{2}{*}{ Intercept } & $34.5^{*}$ & $40.1^{*}$ & $33.1 *$ \\
\hline & $(2.9)$ & $(3.1)$ & $(3.4)$ \\
\hline $\mathrm{R}^{2}$ (adjusted) & 0.19 & 0.20 & 0.25 \\
\hline
\end{tabular}

Notes: $n=441$; Ordinary Least Squares; 'trainer: for profit' is the omitted provider category;

'country-wide provider' and 'trains in particular Area' (i.e., any trainees present at inspection) and 'year' are dummy variables $(1$ : yes $)$; indicates significant difference from zero $(p=0.05)$

${ }^{a}$ Hundreds of trainees (all programmes, including Apprenticeships) 
Similarly, non-employer providers with low completion rates might be expected to gain an 'adequate' rating as long as they achieved passing grades for procedural attributes. The category is well populated. Defining a low completion rate as one in the lower quartile - here, less than 21 per cent - thirty-eight organisations with low completion rates are rated 'adequate', in association with grades of at least 'satisfactory' for Leadership \& Management. The set comprises twenty training companies, five non-profit training specialists, six employer groups, and seven employers. The share of employers (public and private) is significantly lower than among providers as a whole $\left(\chi^{2}=4.78 ; \mathrm{p}<0.05\right)$. The asymmetry is even greater for private sector employers, with only one (BP Retail, with a completion rate of 18.8 per cent) present. The eight cases with the lowest completion rates, all no greater than six per cent, are listed in panel (II) of Table 7.

This pattern might not however be caused by proceduralist bias against employers' programmes. Providers rated 'inadequate' despite having a high completion rate may perform badly in respect of other substantive attributes, including Learning Sessions and Areas of Learning $(\mathrm{O} / \mathrm{C})$. However, only two of the eight providers in panel (I) of Table 7 - and none of the three private sector employers - were failed on one of those two criteria. Similarly, providers rated 'adequate' despite a low completion rate might be pulled up by other substantive attributes. This interpretation appears more plausible: none of the eight providers in panel (II) was failed for either Learning Sessions or Areas of Learning $(\mathrm{O} / \mathrm{C})$. Even so, the low importance that the inspectors implicitly attached in all those cases to completion rates no greater than six per cent represents a disturbing feature of such inspection 'successes'.

\section{Qualitative findings}

Further evidence can also be derived from the text of inspection reports. We consider two aspects: first, in the more striking cases of employer failure, evidence of the trumping by procedural attributes of qualitative evidence of high training quality, concerning training staff and facilities in particular; second, a tension between tone and content in reports on employers who do pass muster. The specific examples cited here do not represent training practices or inspection outcomes in the round, but they augment the statistical evidence in the previous section.

On the former count, the relevant private sector employers are Honeywell, Swindon Pressings, and United Utilities (Table 7). All offered traditional engineering apprenticeships, all had completion rates exceeding 80 per cent, and all were rated 'satisfactory' for Areas of Learning $(\mathrm{O} / \mathrm{C})$. The text of all three reports contains evidence of a large investment by the employer in dedicated training facilities and staff. Nevertheless, all three were failed for procedural deficiencies. 
Table 7: Attributes of providers with extreme Apprentice completion rates and a contrast with the inspection verdict Ranked by completion rate of entrants to Apprenticeship

\begin{tabular}{|c|c|c|c|c|c|c|}
\hline \multirow[b]{2}{*}{ Provider } & \multirow[b]{2}{*}{ Provider type } & \multirow[b]{2}{*}{$\begin{array}{l}\text { Number } \\
\text { of trainees }{ }^{a}\end{array}$} & \multicolumn{2}{|c|}{ Apprentices' outcomes } & \multicolumn{2}{|c|}{ Grade for } \\
\hline & & & $\begin{array}{l}\text { Retention } \\
\text { rate }\end{array}$ & $\begin{array}{l}\text { Completion } \\
\text { rate }\end{array}$ & $\begin{array}{l}\text { Learning } \\
\text { Sessions }\end{array}$ & $\begin{array}{c}\text { Areas of } \\
\text { Learning }(\mathrm{O} / \mathrm{C})\end{array}$ \\
\hline
\end{tabular}

(I) High completion rate, rated 'inadequate', with 'unsatisfactory' or worse Leadership \& Management (eight highest completion rates)

\begin{tabular}{|c|c|c|c|c|c|c|}
\hline Tyne North Training & Employer group & 219 & 97.4 & 97.2 & n.a. & Satisfactory \\
\hline $\begin{array}{l}\text { Honeywell (Normal-Air } \\
\text { Garrett) Ltd }\end{array}$ & $\begin{array}{l}\text { Employer } \\
\text { (private sector) }\end{array}$ & 24 & 93.0 & 93.0 & n.a. & Satisfactory \\
\hline Swindon Pressings Ltd & $\begin{array}{l}\text { Employer } \\
\text { (private sector) }\end{array}$ & 50 & 94.1 & 92.3 & $\begin{array}{l}\text { Satisfactory/ } \\
\text { Good }\end{array}$ & Satisfactory \\
\hline United Utilities & $\begin{array}{l}\text { Employer } \\
\text { (private sector) }\end{array}$ & 51 & 93.9 & 84.2 & n.a. & Satisfactory \\
\hline $\begin{array}{l}\text { Pennywell Community } \\
\text { Business }\end{array}$ & $\begin{array}{l}\text { Training org. } \\
\text { non-profit }\end{array}$ & 42 & 88.9 & 88.9 & n.a. & Satisfactory \\
\hline Derwentside Training & Local authority & 29 & n.a. & 83.3 & Good & Unsatisfactory \\
\hline Business Insight & Training company & 83 & 83.3 & 83.3 & Unsatisfactory & Satisfactory \\
\hline Royal Air Force & $\begin{array}{l}\text { Employer } \\
\text { (public sector) }\end{array}$ & 5029 & 93.8 & 73.5 & Good & Satisfactory \\
\hline
\end{tabular}


Table 7 , continued

(II) Low completion rate, rated 'adequate', with 'satisfactory' or better Leadership \& Management (eight lowest completion rates)

\begin{tabular}{|c|c|c|c|c|c|c|}
\hline The Training Partnership & Training company & 24 & 14.3 & 0 & Very good & Satisfactory \\
\hline $\begin{array}{l}\text { South Staffs Training } \\
\text { Association }\end{array}$ & Employer group & 95 & n.a. & 2.6 & n.a. & Satisfactory \\
\hline $\begin{array}{l}\text { Bradford Distributive } \\
\text { Training Services }\end{array}$ & Training company & 160 & 23.8 & 3.0 & Good & Satisfactory \\
\hline Touchstone Group & Training company & 2470 & 13.7 & 3.1 & Good & Satisfactory \\
\hline $\begin{array}{l}\text { Bassetlaw Training } \\
\text { Agency Ltd }\end{array}$ & Training company & 39 & 22.4 & 3.4 & Satisfactory & Satisfactory \\
\hline $\begin{array}{l}\text { Skillnet Vocational } \\
\text { Training }\end{array}$ & Training company & 261 & 25.4 & 3.8 & Satisfactory & Satisfactory \\
\hline BTAL (UK) Ltd & Employer group & 160 & n.a. & 4.0 & Very good & Good \\
\hline First Rung Ltd & $\begin{array}{l}\text { Training org } \\
\text { (non-profit) }\end{array}$ & 103 & n.a. & 6.0 & Good & Satisfactory \\
\hline
\end{tabular}

Notes: n.a.: not available, presumably because the inspectors observed no learning sessions.

${ }^{a}$ Number of trainees at inspection in all programmes, including Modern Apprenticeship, in five Areas in selected cohorts 
The report for United Utilities acknowledges the presence of an expensive and ambitious traditional engineering apprenticeship ('the company invests heavily in its modern apprenticeship scheme' ... the company's off-the-job training centre is 'well resourced', with 'extensive and excellent accommodation', 'all assessment is based on real work': $7,13,12$ ). The training is reported to outstrip the requirements of Apprenticeships. It is nevertheless rated 'inadequate' because of procedural weaknesses that include: unclear lines of managerial authority; reactive and uncritical self-assessment ('self-assessment reports were produced in 1998 and 2002, just before inspection' and 'some strengths were no more than normal practice': 10); inadequate internal verification of NVQ assessments; and delays in updating individual training plans to reflect trainees' progress. The criticism that Key Skills training receives insufficient attention sits strangely beside the fact that all entering apprentices held good school leaving qualifications (at least five GCSEs; 11, 14), which should have removed the requirement for additional Key Skills training. ${ }^{24}$

Similarly, the report for Swindon Pressings Ltd. acknowledges the substantive qualities of traditional engineering apprenticeship, as characterised by: generous staffing; a company training school; part-time technical education in the local college; training curricula that exceed the requirements of Apprenticeships; and favourable opportunities for apprentices to progress to higher qualifications. Set against these qualities, the inspectors note a poor coordination of Key Skills training, 'little reinforcement of equal opportunities ... and [poor] learners' understanding [of EO]', 'incomplete' arrangements for quality assurance, weak internal verification of skills assessments, and a weak individualisation of training programmes. The implicit demand for fully individualised training plans ('all learners have the same end dates': 6) is not economically realistic, given the high cost of fully bespoke learning programmes; nor is it applied to university-level learning. ${ }^{25}$

These companies' relations with further education were subject to specific criticism, primarily for the absence of a formal contractual relationship, a weak integration of on-the-job and college-based learning, and deficient monitoring of the college's contribution. Inspection has visibly set its face against the informal trustoriented organisation of traditional apprenticeship, including employers' relations with further education colleges - to the extent that they failed three programmes whose substantive quality was manifestly high.

At the other end of the spectrum, the inspectors of three of the eight providers with the lowest completion rates in Table 7, Touchstone Group, South Staffordshire Training, and First Rung, emphasise favourable procedural attributes, in terms of organisational strategy, the codification of management procedures, and the presence of operating manuals. Learners' attainments are in all cases described as low, but the

\footnotetext{
${ }^{24}$ http://www.ofsted.gov.uk/oxedu_reports/download/(id)/78913/(as)/55164_304831.pdf (2002 report, accessed 25 November 2008). The inspectors appear not to have observed any learning sessions.

${ }^{25}$ http://docs.ali.gov.uk/Inspreps/13/3388DET.PDF (report dated 18 November 2002), accessed 1 May 2007. Neither this nor the Honeywell (Normalair-Garrett) Ltd., report of 11 June 2002 could be traced on the OfSTED website in November 2008.
} 
reports do not bring out just how low they are, nor do they discuss the implications of that fact. Ironically, the first two providers are criticised for the inadequacy of their information about their trainees' outcomes - an essentially procedural failing that is not allowed to tarnish the inspectors' overall assessment, despite the procedural orientation of the reports. ${ }^{26}$

The second type of qualitative evidence suggestive of procedural bias against employer programmes concerns the terminology of inspection reports, as explored, e.g., in Sinkinson (2004) for school inspections. We focus here on employers who, despite being rated 'adequate' overall, have their training programmes described in less than favourable terms, despite evidence of a substantively high quality.

A prominent example is Rolls-Royce (Derby), whose engineering apprenticeship programme showed high rates of retention and completion. Its 2006 inspection report rates both the 'overall effectiveness of provision' and 'Leadership and Management' as only 'satisfactory'; it criticises the company's self-assessment report as 'insufficiently rigorous'; and it even asserts that 'the provider has not demonstrated that it has sufficient capacity to make improvements'. Retention and completion, which we calculate at 79 and 81 per cent, are termed only 'good', even though in our data that would place them more than one standard deviation above the mean for engineering and more than two deviations above that for the five Areas of Learning as a whole. ${ }^{27}$

A more extensive investigation would be required to determine the prevalence of this particular pathology. Even were it only a matter of a grudging tone in reports on providers rated 'adequate', the result could still be an unwarranted impairment of an employer's reputation for training. Employers who nevertheless receive a pass may simply shrug off the inspectors' lack of enthusiasm, knowing that politicians and programme managers need them more than they need the Apprenticeships programme.

Failing an inspection altogether might however be expected to have stronger effects, including leading an employer to withdraw from the Apprenticeship programme. No re-inspection report exists for four of the eight private employers in our dataset who failed inspection, including United Utilities. As re-inspection was mandatory for providers who continued in LSC-funded training, these four employ-

\footnotetext{
${ }^{26}$ http://www.ofsted.gov.uk/oxedu_reports/download/(id)/79094/(as)/57318_305012.pdf and http:// www.ofsted.gov.uk/oxedu_reports/download/(id)/78900/(as)/54490_304818.pdf; accessed 30 November 2008. First Rung is a charity that targets young people with 'learning difficulties and disabilities' from 'diverse social and economic areas'. Of its trainees, 'more than 60 per cent ... have additional social or learning needs', and 'fifty per cent come from minority ethnic groups'. In that context, low achievement rates convey only limited information about training quality (http://www.ofsted.gov.uk/oxedu_reports/download/(id)/78691/(as)/51850_304609.pdf; accessed 30 November 2008). Reports on the remaining providers in Table 11 Panel II could not be located on OfSTED's website in November 2008.

${ }^{27}$ http://docs.ali.gov.uk/Inspreps/31/7880DET.PDF; report of 17 March 2006, accessed 1 May 2007; not traceable on the OfSTED website in November 2008. The previous (24 June 2002) report, from which we calculate retention and completion rates of 87 and 85 per cent respectively, contained similar criticisms but adopted a more appreciative tone.
} 
ers may be taken to have left the programme. As two of them had low completion rates, their exit may have been appropriate. That is however unlikely for the other two, United Utilities and Lincolnshire Co-operative Society, both of which had above average completion rates. ${ }^{28}$

Whether such employers are passed or not, the reputation of the Apprenticeships programme in employer circles can hardly have benefited from the procedural biases of the inspection system, to the potential detriment of employer involvement and commitment.

\section{Conclusions}

The content of inspection reports on providers of publicly-funded Apprenticeships in England suggests that inspection emphasises procedural rather than substantive attributes of training quality, and that this proceduralist bias leads to the under-rating of training programmes that are sponsored by private sector employers, relative to those of other employers, both public sector and group private sector ones, and specialist training organisations, both commercial and non-profit. Programmes sponsored by private employers have much higher completion rates, which we take to be evidence of higher training quality.

The finding is at one level surprising - for various reasons. Many inspection reports allude to learners' achievements. The annual report of ALI's Chief Inspector contained for some years lists of the best and the worst training providers, with the former dominated by private employers and the latter by training companies (e.g., ALI, 2002b). Moreover, the grades given by the inspectors for the attributes on which they concentrated differed little between private employers and other providers, and, if anything, favoured private employers. Finally, the Chief Inspector declared that "... it appears that employers training their own staff have now lost their decisive advantage in terms of quality over commercial providers" (ALI, 2004: 13).

That judgement appears itself to have involved proceduralist bias, but the flaw in the inspection system that it overlooked was not immediately obvious. The superiority of private employers' completion rates was obscured by the weak attention that the inspection system paid to learners' achievements, notwithstanding the requirements of the Common Inspection Framework. But the flaw is substantial, and it survives statistical controls for the tendency of employer provision to focus on single occupation-sector categories with higher completion rates, particularly craft level Apprenticeships in metalworking. Moreover, the defect involves specifically private sector employers: public employers and employer groups are statistically indistinguishable from specialist training bodies.

Our findings are not definitive, as they are subject to selection biases on both the employer and the trainee sides. Employers are involved in the Apprenticeship programme in diverse ways, and our findings refer only to the few that take full

\footnotetext{
${ }^{28}$ The two 'not re-inspected' employers with low completion rates (2.9 and 28.9 per cent respectively) were Jenkins Newell Dunford Group and Topps Tiles.
} 
responsibility for Apprenticeships, by holding the principal contract for public funding. Many more employers are involved simply as providers of work-based learning, subcontracted to specialist trainers. Some of them undoubtedly provide low quality training, using trainees as cheap labour, and contributing thereby to the unfavourable performance of the 'training specialist' categories of provider.

Similarly, selection effects can be anticipated on trainee side, to the extent that private employers offer the best training and employment prospects, and are able as a result to select the best trainees, who are intrinsically more likely to complete their programmes.

A second qualification to our findings is that the proceduralist bias of the inspection system may have fallen since 2005 , the last year covered by our data. Completion rates have risen steadily over the decade, particularly among specialist training bodies (Lewis and Ryan, 2009: Figure 1). The revised Common Inspection Framework places trainees' attainments ahead of organisational attributes in the list of inspectors' priorities (ALI-OfSTED, 2005). The LSC adopted in 2006 an algorithm for computing a provider's completion rates; recent inspection reports on providers of work-based learning both present and process data on learners' attainments (LSC, 2006). The acid test is however whether such changes amount to more than windowdressing when it comes to the overall inspection verdict. A similar statistical analysis of more recent data would be required to answer that question. Were the answer favourable to inspection, the under-rating of the training programmes of private sector employers to which we have pointed would be expected to have declined.

In any case, the government continues to express its concern to raise completion rates in, and to increase employer engagement with, the Apprenticeships programme. Thus a recent policy innovation, which increases public spending in order to expand the programme, focuses entirely on employers with 'high quality' programmes (LSC, 2008).

Our results suggest however that the inspection system to some extent frustrates the attainment of both goals. A better understanding of the contribution of private employers might lead the government both to induce more to take full responsibility for their training programmes, and to point its inspectorate to the benefits of their doing so - to the potential benefit of both Apprentice attainments and overall training quality. ${ }^{29}$

\section{References}

ALI (2002a). A guide to inspection. Coventry: Adult Learning Inspectorate.

ALI (2002b). Annual report of the Chief Inspector, 2001-2002. Coventry: Adult Learning Inspectorate. ALI (2004). Annual report of the Chief Inspector, 2003-2004. Coventry: Adult Learning Inspectorate.

\footnotetext{
${ }^{29}$ The case for encouraging employers to act as principal contractors for Apprenticeships weakens to the extent that the mechanism linking employer sponsorship to performance is the selection of organisations that intrinsically provide better training rather than the causal effect on training (e.g., through greater commitment) of taking full responsibility for it.
} 
ALI-OfSTED (2001). The Common Inspection Framework for inspecting post-16 education and training. Coventry: Adult Learning Inspectorate.

ALI-OfSTED (2005). The Common Inspection Framework: for inspecting education and training. Coventry: Adult Learning Inspectorate.

Chalkey, M. \& Malcomson, J.M. (2000). Government purchasing of health services. In A.J. Culyer \& J.P. Newhouse (Eds.) Handbook of health economics, vol 1a. Amsterdam: Elsevier.

DfES (2001a). Modern Apprenticeships: the way to work. Report of Modern Apprenticeship Advisory Committee. London: Department for Education and Skills.

DfES/LSC (2004). 21st century apprenticeships: end to end review of the delivery of Modern Apprenticeships. London: Department for Education and Skills/Learning and Skills Council.

DfES (2007). Further education and work-based learning for young people - learner outcomes in England 2005/06. Statistical First Release, ILR/SFR13, April (http://www.dfes.gov.uk/rsgateway/DB/ SFR/s000723/index.shtml).

Dustmann, C. \& Schönberg, U. (2008). Why does the German apprenticeship system work? In K.U. Mayer \& H. Solga (Eds.) Skill formation: interdisciplinary and cross-national perspectives. Cambridge: CUP.

Fuller, A. \& Unwin, L. (2008). Towards expansive apprenticeships. Teaching and Learning Research Programme. London: Institute of Education.

Hogarth, T. \& Hasluck, C. (2003). Net costs of Modern Apprenticeship training to employers. Research Report 418. London: Department for Education and Skills.

Lewis, P.A. (2009). Quasi-markets. In N.F.B. Allington \& J.S.L. McCombie (Eds.) The Cambridge student handbook in economics. forthcoming. Cambridge: Cambridge University Press.

Lewis, P.A., Gospel, H. \& Ryan, P. (2008). A hard sell? The prospects for apprenticeship in British retailing. Human Resource Management Journal, 18(1), 3-19.

Lewis, P. \& Ryan, P. (2009). The role of external inspection in the public services: the case of the UK training market. Forthcoming, Public Administration.

LSC (2003a). Requirements for funding work-based learning for young people 2003/04. Coventry: Learning and Skills Council.

LSC (2003b). Work-based learning provision: factors affecting quality and performance. Evidence from the West Midlands. Coventry: Learning and Skills Council.

LSC (2004). Quality improvement strategy 2003 to 2006. Coventry: Learning and Skills Council.

LSC (2005). Further education, work-based learning for young people and adult and community learning - learner numbers in England 2004/05. Statistical First Release ILS/SFR08, 8 December. Coventry: Learning and Skills Council.

LSC (2006). Piloting new measures of success: the quality improvement pack, January 2006 Update. Coventry: Learning and Skills Council.

LSC (2008). Government launches £10m apprenticeship extension. Press Release, 1st December. Coventry: Learning and Skills Council.

Macleod, W.B. (2007). Reputations, relationships and contract enforcement. Journal of Economic Literature, 45 (2), 595-628.

Perry, N. \& Sherlock, D. (2008). Quality improvement in adult vocational education and training: transforming skills for the global economy. London and Philadelphia: Kogan Page.

Pierson, P. (1996). The new politics of the welfare state. World Politics, 48, 143-79.

Power, M. (1999). The audit society: rituals of verification, 2nd ed. Oxford: Oxford University Press.

Rose, R. \& Wiganek, G. (1990). Training without trainers: how Germany avoids Britain's supply-side bottleneck. London: Anglo-German Foundation.

Ryan, P. (2000). The institutional requirements of apprenticeship: evidence from smaller EU countries. International Journal of Training and Development, 4 (1), 42-65.

Ryan, P. (2009). The training market. In B. McGaw, E. Baker \& P.P. Petersen (Eds.) International Encyclopaedia of Education, $3 r d$ ed.. Forthcoming. Oxford: Elsevier.

Ryan, P., Gospel, H. \& Lewis, P. (2006). Educational and contractual attributes of the apprenticeship programmes of large employers in Britain. Journal of Vocational Education and Training, 58 (3), 359-83.

Ryan, P., Gospel, H. \& Lewis, P. (2007). Large employers and apprenticeship training in Britain. British Journal of Industrial Relations, 45 (1), 127-53. 
Ryan. P. \& Unwin, L. (2001). Apprenticeship in the British "training market". National Institute Economic Review, 178, 99-114.

Schweri, J., Mühelemann, S., Pescio, Y., Walther, B., Wolter, S.C. \& Zürcher, L. (2003). Kosten und Nutzen der Lehrlingsausbildung aus der Sicht Schweizer Betriebe. Zurich: Verlag Rüegger.

Sinkinson, A. (2004). Manager, moderator, motivator or what? Does ensuring consistency of reporting fall within the role of the Managing Inspector in initial teacher training Ofsted Inspections? Educational Review, 56 (3), 235-246.

Smits, W. (2005). The quality of apprenticeship training: conflicting interests of firms and apprentices. Maastricht: Researchcentrum voor Onderwijs en Arbeidsmarkt.

Stevens, M. (1996). Transferable training and poaching externalities. In A. Booth \& D. Snower (Eds.) Acquiring skills: market failures, their symptoms and policy responses. Cambridge: Cambridge University Press.

Ullman, A. \& Deakin, G. (2005). Apprenticeship pay: a survey of earnings by sector. Research Report no. 674. London: Department for Education and Skills.

Von Bardeleben, R., Beicht, U. \& Féher, K. (1995). Betriebliche Kosten und Nutzen der Ausbildung: representative Ergebnisse aus Industrie, Handel und Handwerk. Bielefeld: Bertelsmann.

Weiner, G. (2002). Auditing failure: moral competence and school effectiveness. British Educational Research Journal, 28, 789-803.

Winterbotham, M., Adams, L. \& Lorentzen-White, D. (2000). Modern Apprenticeships: exploring the reasons for non-completion in five sectors. Research Report 217. London: Department for Education and Employment. 